ISSN: 2224-0616

Int. J. Agril. Res. Innov. \& Tech. 3 (1): 26-28, J une, 2013 Available online at http:/ / www.ijarit.webs.com

\title{
DEVELOPMENT AND EVALUATION OF A DRUM SEEDER FOR ONION
}

\author{
M.A. Hoque ${ }^{1}$ and M.A. Wohab ${ }^{2}$
}

Received 2 April 2013, Revised 25 May 2013, Accepted 20 June 2013, Published online 30 June 2013

\begin{abstract}
To achieve optimum yield of onion by placing the seeds at a certain depth in lines, a manually operated drum seeder for onion has been designed, fabricated and tested in Farm Machinery and Postharvest Process (FMP) Engineering Division of Bangladesh Agricultural Research Institute (BARI). The seeder is suitable for the small farmers who have practice of direct seeding of onion under dry land cultivation. The seeder consists of a frame, a PVC drum, furrow openers, furrow closer, wheels and handle. In 2009-2010, the seeder was fabricated in FMP Engineering divisional workshop and tested in experimental plot, BARI, Gazipur. Seed rate of the seeder was $4 \mathrm{~kg} \mathrm{ha}^{-1}$ and field capacity was $0.08 \mathrm{ha} \mathrm{hr}^{1}$. Weight and price of the seeder were $5.5 \mathrm{~kg}$ and Tk 2500 per unit, respectively. In 2010-2011, a drug chain was added in the seeder and field performance evaluation of the seeder was repeated comparing with manual line sowing and traditional broadcasting methods in experimental plot of BARI, Gazipur. There was no significant variation between average yield of onion by using the seeder (13.26 ton ha-1) and in that of manual line sowing (12.90 ton ha-1) but there was significantly higher yield of onion by using the seeder than that in traditional (10.25 ton $\left.\mathrm{ha}^{-1}\right)$. But sowing time (6 h ha-1) was significantly lower for seeder use than manual line sowing ( $48 \mathrm{~h} \mathrm{ha}^{-1}$ ) which contribute to reduce the cost of sowing for direct seeded onion.
\end{abstract}

Keywords: Onion, Drum Seeder, Field Capacity, Yield and Sowing Time

${ }^{1}$ Senior Scientific Officer, F M P Engineering Division, BARI, Gazipur, Bangladesh

${ }^{2}$ Principal Scientific Officer, F M P Engineering Division, B ARI, Gazipur, Bangladesh

*Corresponding author's email: arshadulbari@yahoo.com (M.A. Hoque)

\section{Introduction}

Onion is the most important spices crops grown in Bangladesh. It is cultivated almost throughout Bangladesh and amongst all spices ranks first in production and second in acreage (Asaduzzaman et al., 2012). The area under onion cultivation is about 36,842 ha with annual production of about $8,49,000 \mathrm{mt}$ (BBS, 2007). The national average yield of onion is very low as 6.94 ton ha-1 while the world average yield is about 20.64 ton ha-1 (FAO, 2006). To meet up the demand of increased population, onion production should be increased with lower production cost.

Generally, the onion seeds are sown in nursery and transplanted. Macias et al. (2004) observed that the system of direct seed obtained better yield (18\%), bulb weight (21\%) and precocity (11 days) in comparing to the transplant methods. In case of rain fed condition, the onion seeds are broadcasted to save the labour and the yield of around 4.5 tones ha-1 is obtained. The poor yield is recorded due to non-uniform spacing of seeds that affects the size of the onion bulbs. Considering the fact, an experiment was undertaken on development of a drum seeder for onion for reducing production cost with higher yield in collaboration with Spices Research Centre, Bogra. The objectives of the study were:

a) To develop a manually operated onion seeder by using locally available materials.

b) To test the seeder in laboratory and field conditions.

\section{Materials and Methods}

A drum seeder for onion was designed and fabricated in Farm Machinery and Postharvest Process Engineering Division of Bangladesh Agricultural Research Institute (BARI), Joydebpur, Gazipur during 2009-2010. The design of the drum seeder was drawn by AutoCAD software 2004 and then constructed according to drawing dimensions in the FMP Engineering divisional workshop. The seeder is made of locally available materials like M S flat bar, M S sheet, M S pipe, M S hollow square bar, M S rod, PVC pipe and M S nut bolts etc. The seeder consists of a frame, a drum, furrow openers, wheels and handle. Functional views of the drum seeder for onion are shown in Fig. 1. 


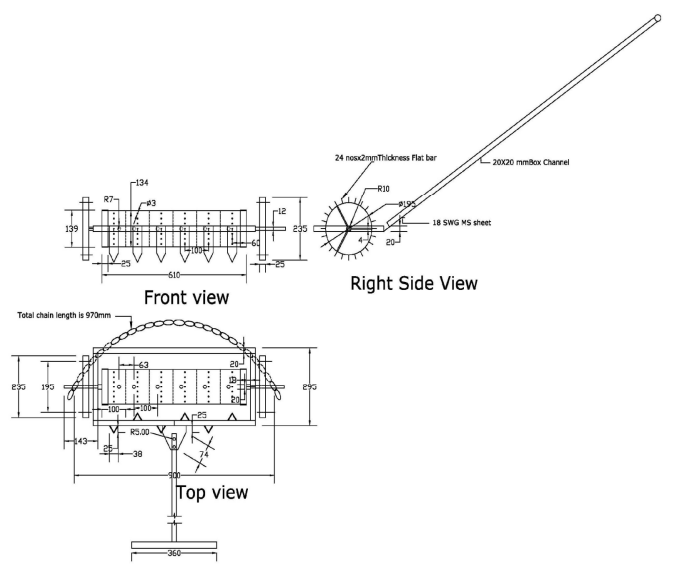

Fig. 1. Functional views of the drum seeder

The functions of the parts of the drum seeder are described briefly as follows.

1) Frame: It is made of MS hollow square bar of $18 \mathrm{~mm}$ size. Length and width of frame is 650 $\mathrm{mm}$ and $300 \mathrm{~mm}$, respectively. Other parts of seeder are fitted with the frame.

2) Wheel: MS flat bar of $18 \mathrm{~mm}$ size was used to make the wheel. There are lugs welded at the out side of round flat bar. Wheel diameter is $195 \mathrm{~mm}$. It is fitted in both side of the drum by a shaft.

3) Drum: PVC pipe of $139 \mathrm{~mm}$ diameter and 610 $\mathrm{mm}$ length was used in the drum. It has holes of $3 \mathrm{~mm}$ diameter size, in 6 rows with spacing of $100 \mathrm{~mm}$ (line to line spacing). To achieve 20 $\mathrm{mm}$ spacing between seeds, the drum has holes along the circumference at a spacing of 13.5 $\mathrm{mm}$. Five partitions are made inside the seeder drum between the rows to avoid accumulation of seeds to one side of the seeder drum. The entire assembly is attached in the middle of the

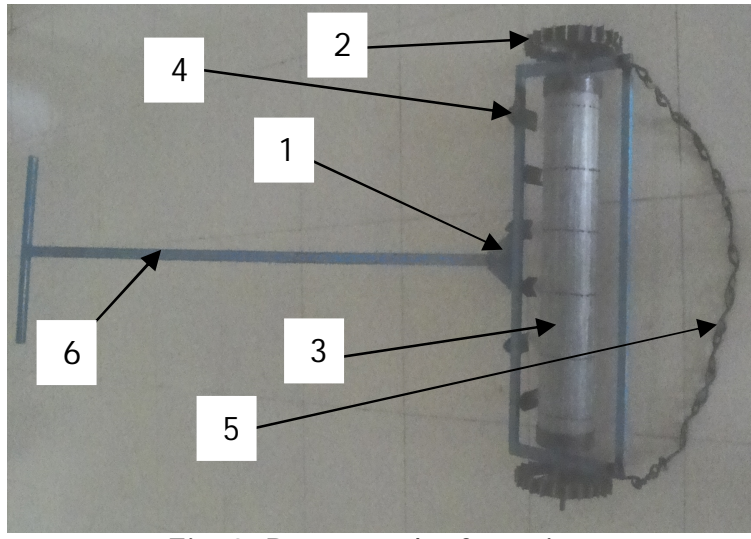

Fig. 2. Drum seeder for onion

\section{Field test}

In 2009-2010, the seeder was tested after fabrication in experimental plot, BARI, Gazipur. In 2010, a drug chain was incorporated to frame. In order to rotate the drum, the seeder is pulled in forward direction.

4) Furrow opener: Single pointed shovel type six furrow openers are fitted to the frame in front of the seeding drum. It is made of MS angle bar.

5) Furrow closer: A $700 \mathrm{~mm}$ long drug chain was used behind the frame to close the furrows.

6) Handle: The seeder has a handle of $1500 \mathrm{~mm}$ length for easy pulling. It is made of MS hollow square bar of $18 \mathrm{~mm}$ size.

A photographic view of the drum seeder for onion and onion field sown by the seeder are shown in Fig. 2 and Fig.3 respectively.

\section{Laboratory test}

To ascertain various design parameters of the seeder, laboratory test was carried out in the FMP Engineering division, BARI, Gazipur. The drum seeder was tested in lab bed to determine the performance parameters. The seeder was calibrated to appraise seed rate and seed depth.

\section{Machine operation}

Before putting the seeds inside the drum, seeds were soaked for 24 hours for sprouting. Then small amount of seeds (100 g) were put inside the drum in each chamber. Seeding operation was started from a corner of the land. After placement the seeder in a corner, the seeder was pulled forward. When the seeder moved forward, wheel as well as the drum rotated and seeds dropped in the furrows made by furrow openers. Then the seeds were covered by drug chain and leveled the land.

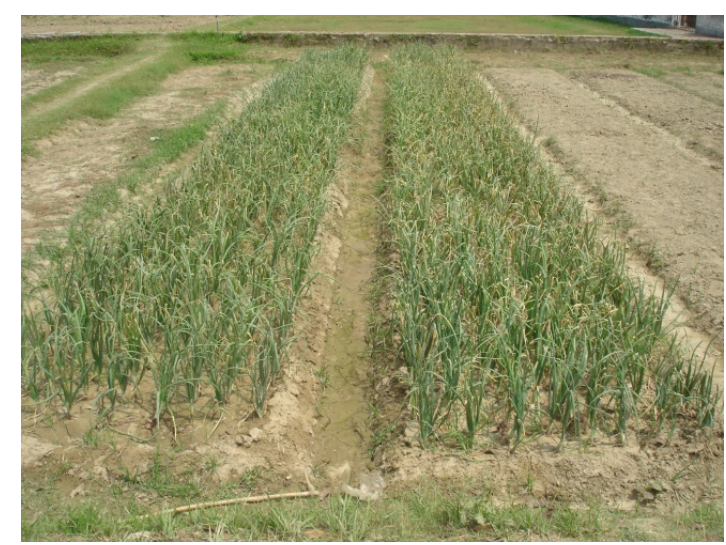

Fig. 3. Onion field seeded by the seeder, Gazipur

improve the seeder performance in divisional workshop and tested in experimental plot, BARI, Gazipur. The seeder was tested with 3 treatments. Treatments were: $\mathrm{T}_{1^{-}}$Seeding by 
seeder; $\mathrm{T}_{2}$ - Hand seeding in line; $\mathrm{T}_{3}$-Broadcast. The seeder was tested in well prepared land. After germination, irrigation and weeding operations were done as and when necessary. At the age of 45 days of plants, excess plants were thinned out and transplanted in other plots.

\section{Results and Discussion}

The test results of the drum seeder in 2009-2010 are shown in Table 1. Width of the seeder was within the reach of an operator to pull it at $1.5 \mathrm{~cm}$ sowing depth. Diameter of the holes in the seeder was $3 \mathrm{~mm}$ to release onion seed easily. It depends

Table 1. Test results of onion drum seeder in 2009-2010

\begin{tabular}{clc}
\hline Sl. No. & Particulars & Results \\
\hline 1 & Seeder drum width, mm & 600 \\
2 & Depth of seed sowing, mm & $10-15$ \\
3 & Number of rows & 6 \\
4 & Row spacing, mm & 100 \\
5 & Seed rate, kg ha ${ }^{-1}$ & 4.0 \\
6 & Field capacity, ha h-1 & 0.08 \\
7 & Sowing time, man-day ha- ${ }^{-1}$ & 2 \\
8 & Weight, kg & 5.5 \\
10 & Yield of onion, $\mathrm{kg} \mathrm{ha}^{-1}$ & 10660 \\
\hline
\end{tabular}

Comparative study of drum seeder for onion cultivation with conventional practices is shown in Table 2. There is no significant difference on yield between $T_{1}$ and $T_{2}$. Nevertheless, significantly lowest yield was found in $\mathrm{T}_{3}$ due to less plant population and 100-bulb weight. In $\mathrm{T}_{3}$, plant population was less due to uneven distribution of seed and uneven seed depth.

Table 2. Comparative study of drum seeder for onion cultivation with conventional practices in Gazipur

\begin{tabular}{ccccccc}
\hline Treatment & $\begin{array}{c}\text { Plant } \\
\text { population } \\
\left(\text { Plant/m } \mathrm{m}^{2}\right)\end{array}$ & $\begin{array}{c}\text { Plant } \\
\text { hight } \\
(\mathrm{cm})\end{array}$ & $\begin{array}{c}\text { Bulb dia. } \\
(\mathrm{cm})\end{array}$ & $\begin{array}{c}100 \text { bulb } \\
\text { weight } \\
(\mathrm{kg})\end{array}$ & $\begin{array}{c}\text { Yield } \\
\text { (ton ha-1) }\end{array}$ & $\begin{array}{c}\text { Sowing time } \\
\left(\mathrm{hr} \mathrm{ha}^{-1}\right)\end{array}$ \\
\hline $\mathrm{T}_{1}$ & $42 \mathrm{a}$ & 40.36 & 4.41 & $3.56 \mathrm{a}$ & $13.26 \mathrm{a}$ & $6 \mathrm{a}$ \\
$\mathrm{T}_{2}$ & $40 \mathrm{a}$ & 39.16 & 4.43 & $3.41 \mathrm{a}$ & $12.90 \mathrm{a}$ & $48 \mathrm{~b}$ \\
$\mathrm{~T}_{3}$ & $34 \mathrm{~b}$ & 37.86 & 4.40 & $2.85 \mathrm{~b}$ & $10.25 \mathrm{~b}$ & $4 \mathrm{a}$ \\
\hline
\end{tabular}

Conclusion and Recommendations

The seeder was capable to use for onion seed sowing in particular depth $(10-15 \mathrm{~mm})$. The field capacity of the seeder for onion was $0.008 \mathrm{ha} \mathrm{h}^{-1}$. Onion yield of seeder sown field and that of manual line sowing was statistically identical though sowing time was significantly varied. The seeder should be further developed for multi crop use like cucumber, amaranth, carrot, radish etc.

\section{References}

Asaduzzaman, M., Hasan, M.M., Hasan, M.M. and Moniruzzaman, M. 2012. Quality seed production of onion (Allium cepa L.): an integrated approach of bulb size and plant spacing. J . Agril. Res. 50 (1): 119-128. on the variety of the onion seed. Average geometric mean diameter of the onion seed was observed 1.98mm (Chhina and Sharma, 2011). Seed rate of the seeder was $4 \mathrm{~kg} \mathrm{ha}^{-1}$. But 45 days after sowing, plants were thinned out keeping optimum plant population. The field capacity of the seeder was $0.08 \mathrm{ha} \mathrm{hr}^{-1}$. Weight of the seeder was $5.5 \mathrm{~kg}$, which was comfortable for the operator to turn at head of the land. The price of the seeder (Tk 2500) was also reasonable for an onion growing farmer.
However, there was no significant variation of sowing time between treatment $\mathrm{T}_{1}$ and $\mathrm{T}_{3}$, but sowing time of onion was significantly highest in $\mathrm{T}_{2}$ than $\mathrm{T}_{1}$ and $\mathrm{T}_{3}$.
BBS. 2007. Statistical Bulletin of Bangladesh. Bangladesh Bureau of Statistics, Ministry of Planning, Government of the Peoples Republic of Bangladesh.

Chhina, R.S. and Sharma, A.D. 2011. Studies on physical properties of onion seeds (Allium cepa L.). Prog. Hort. 43 (1): 76-80.

FAO. 2006. Bulletin of Statistics. Food and Agriculture Organization of the United Nations, Rome.

Macias, R., Grijalva, R.L., Valenzuela, M.J . and Robles, F. 2004. Yield and quality of onion varieties under direct seed and transplant seedling. Hort. Sci. 39 (4): 801. 